\title{
Electrophoretically detectable protein variation in natural populations of the lone star tick, Amblyomma americanum (Acari: Ixodidae)
}

\author{
L. R. Hilburn and \\ P. W. Sattler
}

U.S. Livestock Insects Laboratory, Agricultural Research Service, U.S. Department of Agriculture, P.O. Box 232, Kerrville, TX 78029-0232, U.S.A.

Nine populations of Amblyomma americanum (L.) were examined electrophoretically for variation of 21 enzymes. Only three enzymes were not polymorphic and the average heterozygosity per individual (h) for the species was 0.085 with a range of 0.077 to $0 \cdot 110$, comparing well with values in other arthropods. The average Nei identity value for pairwise comparisons among the nine populations was high, 0.994 \pm 0.004 (I \pm SD). These high identity values and the absence of geographic structuring of the protein variation suggest that this species is genetically homogeneous. Normal levels of genic variability within and a lack of divergence between populacions were not predicted by models developed to describe these genetic characteristics on the basis of the heterogeneities encountered by parasites in their environment. An analysis of data from several different species of ticks suggests host mobility and abundance, as well as tick abundance and selectivity in choosing a host, are important parameters in determining genetic variation in these ectoparasites.

\section{INTRODUCTION}

The questions of how much genetic variability occurs in species of ectoparasites and how that variation is distributed among populations have received little attention. Mayr (1963) and White (1978) pointed out the trend that evolutionary divergence has proceeded more extensively in parasite groups that were selective in their host preference than in groups that exhibited a nonparticular host selection. Price $(1977 ; 1980)$ defined a parasite by the immediacy of the relationship between individual organisms and a single host (rather than the degree of feeding preference of the parasite species) and applied the theory of fitness sets and adaptive functions (Levins, 1962; 1963; 1968) and environmental grain (MacArthur and Levins, 1964) to conclude that genetic variation within populations of parasites would be small and variability between populations of parasites would be large.

Empirical evidence that addresses the issue of genetic variability in ticks has tended to support Price's ecological view. Wallis and Miller (1983) examined three populations of two species of Ornithodoros ticks electrophoretically for nine enzymes. They found within-population heterozygosity values generally less than 5 per cent. Bull et al. (1984) analysed enzymes electrophorectically in 65 populations representing six Australian reptile tick species of the genera Aponoma and Amblyomma. The heterozygosity values they reported for these six species were all less than $2 \cdot 5$ per cent. The heterozygosities reported by these authors are very low when compared to a value of 11.2 per cent presented by Nevo (1978) as the average for invertebrates.

The degree of inter-population divergence within species observed in these studies was smaller than predicted by Price's (1977) theory. The genetic identity (Nei, 1972) between conspecific populations of Ornithodoros ticks (not reported, but calculated by us from data reported by Wallis and Miller (1983)) was 0.983. Bull et al. (1984) reported genetic identities between conspecific populations of reptile ticks that were greater than $0 \cdot 940$. For comparison, the maximum value for the Nei identity statistic (I) is $\mathbf{1 . 0}$ and Ayala et al. (1975) list an average genetic identity of 0.970 for comparisons of conspecific populations, a value of 0.795 for between subspecies comparisons, and 0.352 for interspecific comparisons.

In contrast to the results of these studies, the average heterozygosity observed in five temporal and geographic populations of Ixodes ricinus (L.) 
for $\alpha$-glycerophosphate dehydrogenase was $53 \cdot 3$ per cent \pm 1 per cent (Healy, 1979b) and the average heterozygosity calculated by us as the arithmetic mean of values published for phosphoglucose mutase was 66.9 per cent \pm 2.4 per cent (Healy, 1979a). Although Healy was reporting genetic studies and must have worked with the most polymorphic loci he found, neither theory nor empirical results predicted these high heterozygosity values. Nor does the theory explain observations on Boophilus microplus (Canestrini) (Sattler et al., in press). For the 23 enzymes studied in natural populations or recently established colonies from eight North American localities, the average heterozygosity was 9.1 per cent \pm 0.8 per cent, twice those previously reported in population comparisons in other ticks. The average genetic identity between the eight $B$. microplus populations did not conform to theoretical predicions either, although the high values $(I=0.985 \pm 0.013)$ did agree well with results of the other tick comparisons.

The purpose of the present study was to determine how much genetic variation occurs in the lone star tick, Amblyomma americanum (L.), and how it is distributed across the species range. The results of the electrophoretic examination are compared to those reported for the other species and differences discussed in the light of Price's (1977) theory. This comparison is appropriate because $A m b$. americanum is in the same sub-family as the Australian reptile ticks and all are three-host ticks (i.e., each of their three life stages, larva, nymph, and adult, feeds on a different host). The lone star tick differs from the reptile ticks in being one of the few truly non-particular feeders among the ticks (Hoogstraal and Aeschlimann, 1982). Boophilus is not as closely related, but is a Metastriate hard tick that, like the reptile ticks, has a high degree of host specificity and infests large mammals as does Amb. americanum. Since Ornithodoros species are soft ticks whose biology differs substantially from that of the Metastriate ticks, they will not be discussed in detail.

\section{MATERIALS AND METHODS}

During the summer of 1984, samples of $A m b$. americanum (adults and nymphs) were obtained, either by the authors or from cooperators, at nine localities throughout the species range (fig. 1). The nine localities, identity code, and numbers of each sex obtained from each are as follows: Texas Tech University Center at Junction, Texas (JT; 50 ㅇ, 25 ð); Henke Ranch, N. of Kerrville, Texas (KT,
141 \% 10 đ); Bastrop State Park, Bastrop, Texas (BT; 16 \&, 1 б); Cameron, Oklahoma (OK; 84 \%, $\left.51 \delta^{\circ}\right)$; Land Between the Lakes ${ }^{\circledR}$, Kentucky (KY; 56 \% 41 ठ); Camp Blanding, Florida (FL; 24 ㅇ, $\left.11 \delta^{*}\right)$; McClellanville (1,$\left.+ 2 \delta^{\circ}\right)$ and Greeleyville, South Carolina (SC; 23, 13 o); Blackstone, Virginia (VA; 41 \%, 24 ); Colts Neck, New Jersey (NJ; $46 \%, 40 \delta)$. As samples were obtained, the adults were placed into mating chambers made by gluing stockinette sleeves onto the sides of Hereford steers held in stanchions. When the ticks had fed, they were stored in liquid nitrogen until used for electrophoretic analysis. Nymphs were fed immediately on a steer, held in incubators at $24^{\circ} \mathrm{C}, 85$ per cent $\mathrm{RH}$ and 12 hour light: 12 hour dark photoperiods until they molted, and these adults were then treated as described above.

The method of preparation of ticks for electrophoresis and electrophoretic procedures were those standard for this laboratory (Sattler et al, in press). Electrophoretic conditions were modified to maximise band resolution. The enzymes examined and the buffers used to resolve them are as follows: Tris-Citric $p \mathrm{H}=8 \cdot 1$ buffer (Buffer C of Hilburn and Rai, 1981): Inorganic Pyrophosphatase (PP, EC 3.6.1.1, 1 zone of staining), Hexokinase (HK, 2.7.1.1, 2 zones), Pyruvate Kinase (PK, 2.7.1.40, 1 zone) and Adenylate Kinase (ADK, 2.7.4.3, 1 zone); Tris-Citric $p \mathrm{H}=$ 6.7 buffer (the continuous tris-citrate I of Sealander et al., 1971): Isocitrate Dehydrogenase (IDH, 1.1.42, 2 zones) and Malic Enzyme (ME, 1.1.1.40, 1 zone); Tris-Glycine buffer (Buffer D of Hilburn, 1980): Peptidase (PEP, 3.4.11, 1 zone); Lithium Hydroxide buffer (LiOH Buffer of Sealander et al., 1971): Esterase (EST, 3.1.1.1, 2 zones); N-(3-Amino-propy 1)-Morpholine-Citric $p \mathrm{H}=6.5$ buffer (Clayton and Tretiak, 1972): Malate Dehydrogenase (MDH, 1.1.1.37, 2 zones), Catalase (CAT, 1.11.1.6, 1 zone), and Phosphoglucose Isomerase (PGI, 5.3.1.9, 1 zone); N-(3Amino-propy1)-Morpholine-Citric $\quad p \mathrm{H}=7.0$ buffer: $\quad \alpha$-Glycerophosphate Dehydrogenase ( $\alpha$ GPD, 1.1.1.8, 1 zone), Aconitase (ACON, 4.2.1.3, 2 zones), Triosephosphate Isomerase (TPI, 5.3.1.1, 1 zone), Lactate Dehydrogenase (LDH, 1.1.1.27, 1 zone) and Glutamate Dehydrogenase (GDH, 1.4.1.3, 1 zone).

The females of each population were electrophoresed first and for all enzyme systems. Males, being smaller than females, gave poor results if diluted sufficiently to study all enzymes. Therefore, males were examined for only those enzymes shown to be polymorphic in females of the same population. 


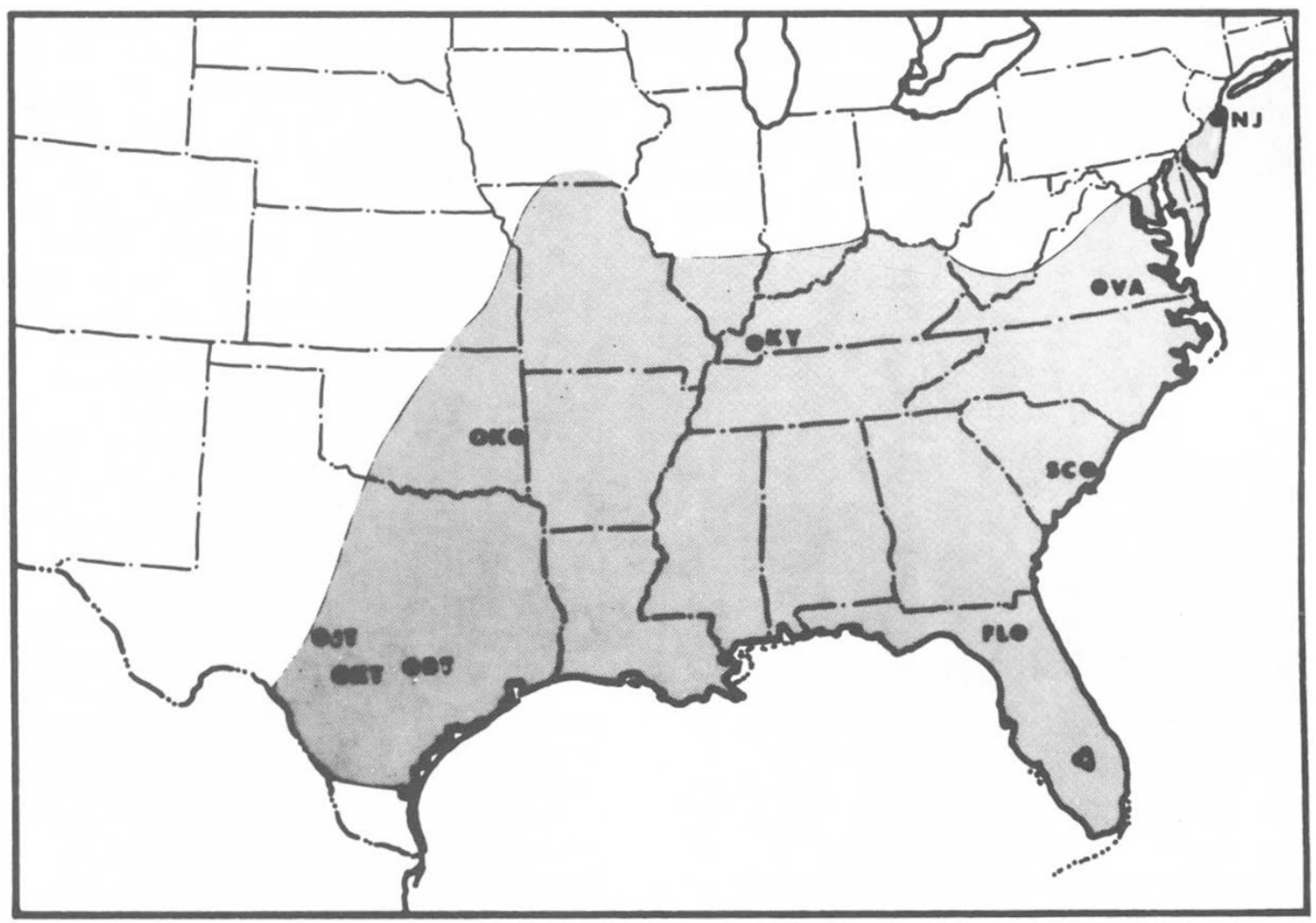

Figure 1 The range of Amblyomma americanum (after Bishopp and Trembley, 1945) in the United States. Solid dots are the collection sites from which came the samples analyzed for isozyme variation. Identification codes are defined in text.

\section{RESULTS}

The procedure given above yielded electromorph information on 21 presumed gene products in 16 enzyme systems. HK-1 and TPI-1 yielded no variants in any population. $\mathrm{LDH}, \mathrm{CAT}, \mathrm{MDH}-1$ and -2, IDH- 1 and -2, PEP, ME, PGI and $\alpha$ GPD exhibited 3-banded heteromorphic phenotypes typical of dimeric proteins. The other proteins, including $\mathrm{ACON}-\mathrm{A}$ and $-\mathrm{C}, \mathrm{ADK}, \mathrm{PK}, \mathrm{HK}-2$, GDH, PP and EST-2 and -3 had 2-banded heteromorphic patterns typical of monomeric proteins. In PGI and ADK, only females exhibited a heteromorphic pattern; males were always homomorphic. Since in Amb. americanum females are XX and males are XO (Oliver, 1977), the electrophoretic results can be explained if PGI and ADK are sex-linked. This explanation has been confirmed by Mendellian analysis (Sattler and Hilburn, unpublished data). The other enzymes exhibited autosomal inheritance.
For calculation of heterozygosities and polymorphisms, an enzyme was considered to be polymorphic if its most common form had a frequency less than 0.99 or if a variant of the enzyme was observed in several populations. Table 1 gives electromorph frequencies for the 19 polymorphic enzymes. HK-1, TPI-1, and LDH were not polymorphic by these criteria. The mean proportion of enzymes polymorphic per population was $P=$ 0.429 (range $0 \cdot 318-0 \cdot 591$ ). The average observed heterozygosity per locus was $h=8.5$ per cent (range 7.7 per cent-11.0 per cent).

The variation among these enzymes was not evenly distributed across the range of the species. ACON-A, MDH-2, IDH-2, GDH, PK, and PP were more polymorphic in populations east of the Mississippi River than in populations west of the river. MDH-1 and PEP were more polymorphic in the west. ADK allozyme 0.60 was found only in the west, allozyme 0.91 was found only in the east, and both forms were present in the Kentucky popu- 
Table 1 Electromorph frequencies of 19 genes polymorphic in natural Amblyomma americanum populations. Population identification codes refer to text.

\begin{tabular}{|c|c|c|c|c|c|c|c|c|c|}
\hline & KT & BT & $\mathbf{J T}$ & OK & KY & FL & $\mathrm{SC}$ & VA & NJ \\
\hline \multicolumn{10}{|c|}{ 1. Catalase (CAT) } \\
\hline $1 \cdot 00$ & 0.972 & $1 \cdot 00$ & 0.991 & $1 \cdot 00$ & 0.988 & 0.980 & 1.00 & 1.00 & 0.989 \\
\hline 0.58 & 0.028 & - & 0.009 & - & 0.012 & 0.020 & - & - & 0.011 \\
\hline$N$ & 151 & 17 & 57 & 66 & 80 & 25 & 24 & 44 & 45 \\
\hline
\end{tabular}

2. Phosphoglucose Isomerase (PGI)

$\begin{array}{llllllllll}1.11 & - & - & - & 0.005 & 0.007 & - & - & - \\ 1.00 & 0.938 & 0.952 & 0.904 & 0.967 & 0.938 & 1.00 & 0.968 & 0.972 & 1.00 \\ 0.82 & 0.062 & 0.048 & 0.096 & 0.028 & 0.055 & - & 0.032 & 0.028 & - \\ N & 151 & 21 & 75 & 126 & 92 & 35 & 39 & 65\end{array}$

3. Malate Dehydrogenase, Zone $1(\mathrm{MDH} 1)$

$\begin{array}{lllllllll}1.75 & 0.003 & - & 0.008 & 0.016 & 0.005 & - & - & 0.008 \\ 1.00 & 0.993 & 1.00 & 0.984 & 0.984 & 0.984 & 1.00 & 1.00 & 0.992 \\ 0.25 & 0.004 & - & 0.008 & - & 0.011 & - & - & -1.00 \\ N & 151 & 21 & 62 & 126 & 97 & 31 & 39 & 61\end{array}$

4. Malate Dehydrogenase, Zone $2(\mathrm{MDH} 2)$

$1 \cdot 12$

$1 \cdot 08$

1.00

0.85

$0 \cdot 69$

$\begin{array}{ll}0.003 & - \\ 0.990 & - \\ -0.007 & -\end{array}$

-

$-$

$\overline{0.016}$

N

$$
147
$$

63

$\overline{0.012}$

126

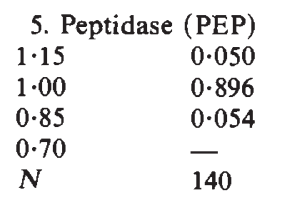

$0 \cdot 042$

0.916

0.042

$0 \cdot 026$

0.947

0.026

$\overline{12}$

57

6. Aconitase, Cathodal Zone (ACON-C)

$1 \cdot 61$

$1 \cdot 33$

$1 \cdot 16$

$1 \cdot 00$

$0 \cdot 22$

N

$\begin{array}{lll}0.003 & - & - \\ 0.430 & 0.333 & 0.473 \\ - & - & - \\ 0.550 & 0.667 & 0.500 \\ 0.017 & - & 0.027 \\ 150 & 21 & 75\end{array}$

$\overline{0.390}$
$\overline{0.610}$
$\overline{105}$

0.021
0.911

0.068

$-$

7. Aconitase, Anodal Zone (ACON-A)

$1 \cdot 05$

$1 \cdot 00$
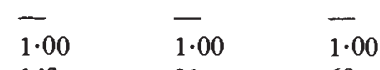

$\overline{1 \cdot 00}$

$\overline{1 \cdot 00}$

69

127

92

-
$\overline{0.979}$
$\overline{0.021}$
97

-

0.014

0.014

$-$

0.039

0.894

0.050

0.017

90

0.005

$0 \cdot 313$

$\overline{0.682}$

-

$$
21
$$

$\begin{array}{ll}0.094 & - \\ 0.906 & 1.00 \\ 16 & 67\end{array}$

0.004
0.996

125

$\begin{array}{ll}0.011 & - \\ 0.989 & 1.00 \\ 94 & 33\end{array}$

0.028

$1 \cdot 33$

1.00

$N$

$\begin{array}{ll}\overline{1 \cdot 00} & 1 \cdot 00 \\ 143 & 13\end{array}$

$-$

51

0.972

125

0.005
0.995

94

10. Isocitrate Dehydrogenase, Zone 2 (IDH2)

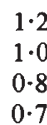

$1 \cdot 28$
$1 \cdot 00$
$0 \cdot 88$
$0 \cdot 76$
$N$

$\begin{array}{lll}0.003 & - & - \\ 0.994 & 1.00 & 1.00 \\ 0.003 & - & - \\ - & - & - \\ 151 & 16 & 61\end{array}$

$\overline{0.986}$

0.014

$\overline{104}$

$\begin{array}{ll}- & 0.015 \\ 0.979 & 0.955 \\ 0.021 & 0.030 \\ \overline{94} & -\end{array}$

-
$1 \cdot 00$
32
$0 \cdot 015$
$0 \cdot 955$
$0 \cdot 030$
-
33

0.015
0.971
0.015
-

-
0.979
0.021
-

0.019
0.971

0.010

0.967

-

- 52

0.011

46

$0 \cdot 030$

84 
Table 1-continued

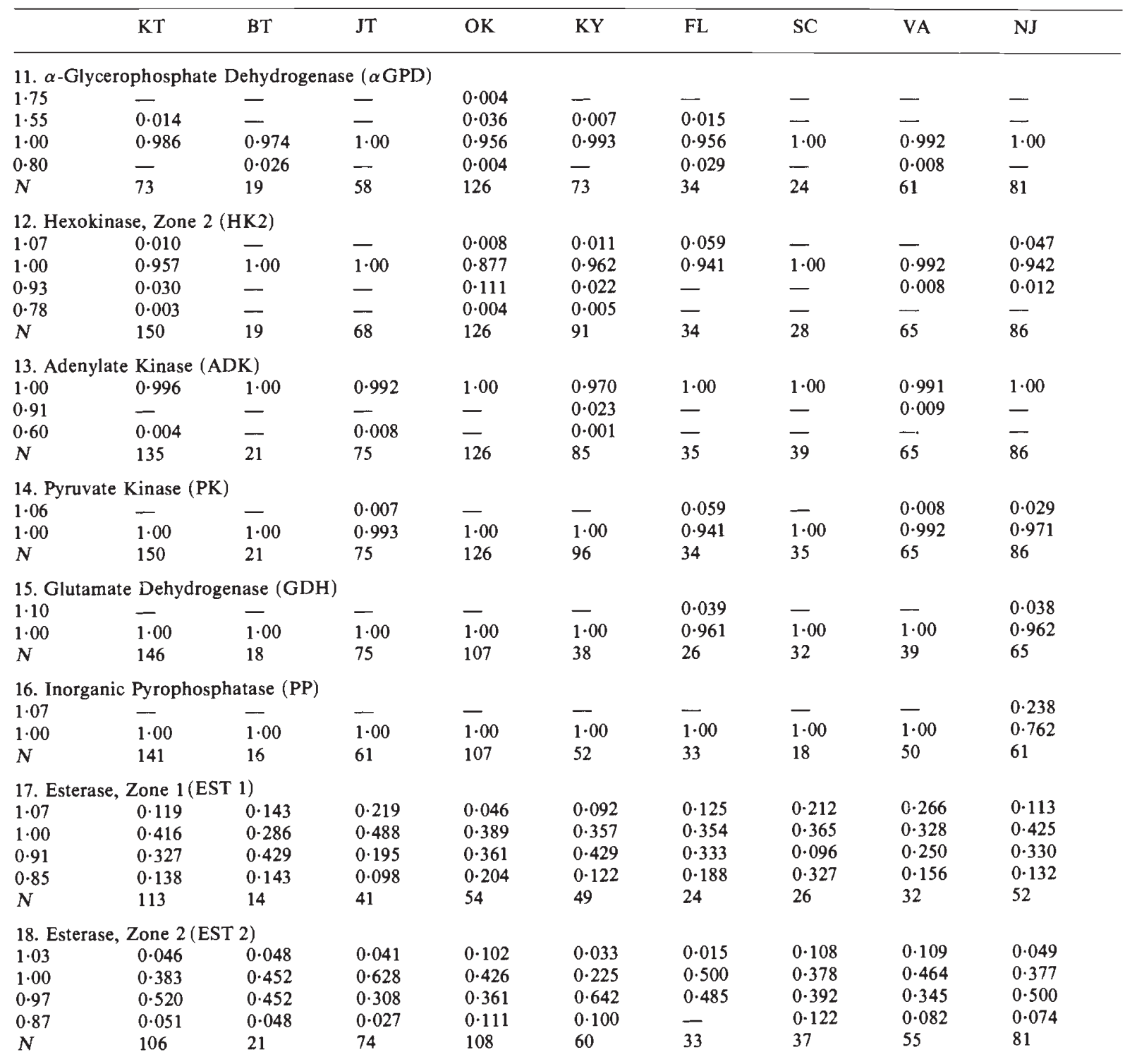

lation. Finally, for IDH-1, an infrequent allozyme was found in Oklahoma and Kentucky, but was not observed in any other sample. Because none of the uncommon variants of these enzymes had high frequencies, the data were significantly heterogeneous $(\mathrm{P}<0.001)$ as determined by a test for homogeity among frequencies (Snedecor and Cochran, 1967), but there was no significant difference between pooled electromorph frequencies from the western and eastern populations, using a t-test for the difference between two frequencies (Sokal and Rohlf, 1969). Thus, separate populations differ from the species as a whole, but no geographically defined group of samples differed from the others.

The enzymes CAT, ACON-C, EST-2, and EST3 , the latter three being the most polymorphic in the study, revealed no geographic patterns in the frequencies of their electromorphs. The differences among these enzymes seemed to result more from random effects and the vagaries of sampling the gene pools.

An analysis of enzyme similarities among populations of $A m b$. americanum was performed using a personal computer computation (Sattler and Hilburn, 1984) of Nei's (1972) identity statistic 

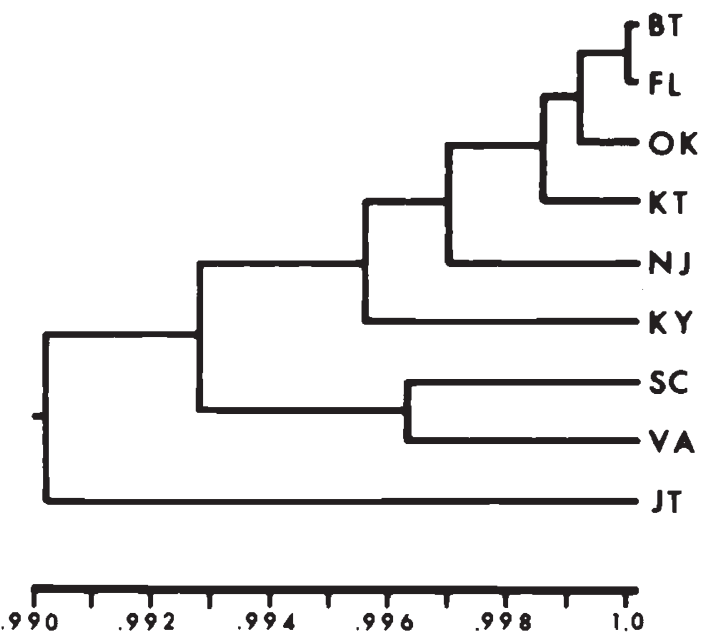

Figure 2 The dendogram reflecting isozyme similarities among nine populations of Amblyomma americanum produced by submitting Nei identity values to an unweighted pair-group clustering procedure using arithmetic averages (U.P.G.M.A.). For population identity codes refer to text.

with modifications by Nei (1978), Mueller and Ayala (1982), and Hillis (1984). The results are summarised in a dendrogram (fig. 2) obtained by submitting the pair-wise identities to an unweighted pair-group method of clustering using arithmetic averages (UPGMA, Sneath and Sokal, 1973).

Two results are striking. First, the mean identity for all possible comparisons was very high at $0.9942 \pm 0.0044(\mathrm{I} \pm \mathrm{SD})$. The smallest average identity value between any clusters in the phenogram was only 0.990 . In fact, the smallest identity value between any two populations was 0.979 , that between Junction, TX, and Kentucky.

A second result is that there was no clear geographic pattern in the genetic variation. Whatever the meaning of the patterns observed in electromorph frequencies of MDH-2, IDH-2, and PEP, and the minor polymorphic genes, the differences were not great enough to affect the clustering of the populations. There is clearly no relationship between geographic distance and genetic identity values.

Another method for estimating the amount of interpopulation divergence relative to intrapopulation variation is by comparing the F-statistics (Wright, 1951) evaluated from enzyme data. Using the nine geographic samples as subdivisions of $A m b$. americanum, the $F$-statistics were calculated for all 21 enzymes by the procedure of Weir and Cockerham (1984). The value for $F_{I T}$ (correlation between two gametes united to produce an individual relative to the total population) was $0.089 \pm 0.036(\mathrm{X} \pm \mathrm{SD})$; the value for $F_{I S}$ (correlation between two gametes united to produce an individual relative to its subdivision) was $0.054 \pm$ 0.051 , and the value of $F_{S T}$ (the correlation between two gametes drawn randomly from different subpopulations) was $0 \cdot 037 \pm 0 \cdot 020$. The statistic $F_{S T}$ measures the genetic differentiation between populations. The low value of $F_{S T}$ compared to $F_{I T}$ and $F_{I S}$ further suggests a lack of interpopulation divergence over the range of $A m b$. americanum.

\section{DISCUSSION}

The empirical evidence obtained from electrophoretic studies of Amb. americanum populations does not match the patterns Price's (1977) model predicts for a parastitic species: "small, relatively homozygous populations with little gene flow between populations, which results in many specialised races, rapid evolution, and speciation without geographic isolation, and an abundance of sibling species" (Price, 1977). Instead the lone star tick is revealed as a variant rich species that exhibits little interpopulation divergence. Certain populations, e.g., that from New Jersey, have both qualitative and quantitative allozyme characteristics that distinguish them, but in no case do these differences seem sufficiently unique as to suggest true genetic divergence. Instead, these differences appear to result from local, probably transitory, chance events; perhaps even resulting from the vagaries of sampling a genetically undifferentiated species.

Earlier electrophoretic studies had suggested that ticks carried little intraspecific isozyme variation (Wallis and Miller, 1983; Bull et al., 1984; Hunt and Hilburn, 1985). With a broader sampling of a species, the use of a greater number of electrophoretic conditions, and the examination of larger sample sizes, the present study has found only two enzymes (HK-1 and TPI-1) for which there was not at least one variant and only one other enzyme (LDH) that could not be classified as polymorphic by the criteria commonly used. The mean proportion of enzymes polymorphic per population, $\mathrm{P}=0.429$ in Amb. americanum, compares well with those observed in other arthropods (Nevo, 1978) and is slightly higher than the value $\mathrm{P}=0.33$ observed in Boophilus microplus (Sattler et al., in press). However, it is much higher than values obtained for Australian reptile ticks (range: 
0 to 0.085 ; Bull et al., 1984) or in Ornithodoros (range: $0 \cdot 111-0 \cdot 222$; Wallis and Miller, 1983). The average observed heterozygosity per locus, $h=$ 0.085 , is similarly comparable to values of $h$ in other arthropods and the value $h=0.092$ observed in $B$. microplus, but is much higher than values from other ticks. The comparatively high levels of intrapopulation variation observed in $A m b$. americanum are not predicted by Price's (1977) model of the distribution of genetic variation in parasites, and in this regard these data also differ from those reported in other tick species.

The high values of genetic identity and low value of $F_{S T}$ compared to $F_{I S}$ and $F_{I T}$ that were obtained from these enzyme comparisons suggest that genetic variability in this species is generally evenly distributed over the species range, a result that appears general in the tricks so far examined. Both qualitative and quantitative differences do occur. The New Jersey population had a unique form of $P P$ and the Florida population had two forms of MDH-2 not found in other samples. There were forms of ACON-A and GDH present in population from the southeastern United States, but absent from those populations from Texas and Oklahoma. The genes MDH-2, IDH-2, and PK were more polymorphic in the former populations while PEP and $\mathrm{MDH}-1$ were more polymorphic in the latter. These differences argue for a small degree of geographic structuring, but they were not large enough to affect the measures of genetic relatedness. In fact, studying the gene-by-gene identity comparisons of pairs of populations has revealed that the observed clustering is more the result of lack of geographic structure in the variability of the very hetermorphic ACON-C, EST-2, and EST-3. These enzymes were responsible for lowered interpopulation identity values and their effects generally swamped those attributable to other enzymes. Since there were no recognisable trends in the geographic distributions of allozymes of these letter three enzymes, there were no patterns in the separation of populations. Thus, the high degree of raceation predicted by Price's (1977) model is not observed in Amb. americanum nor any other tick so far examined.

In part, the inability of Price's (1977) model to predict the distribution of genic heterozygosity in $A m b$. americanum may be because this tick does not meet the definition of a parasite upon which Price's arguments are based. There is no permanent association between an individual tick and a single host. Each lone star tick attaches to and feeds on three hosts during its lifetime but leaves each to molt or lay eggs on the ground. Not only can individual $A m b$. americanum not coevolve with a single host, but because the three life stages of the tick are seldom spent on the same order of vertebrate much less of the same species, this tick species cannot coevolve with a single host species. This life history would argue against the subdivision of the species that would lead to the homozygosity, specialisation, and raceation predicted by Price's (1977) model. Moreover, the passage from host to host in this three-host tick should reduce the probability that siblings would remain together to intermate as adults, so long as hosts are plentiful, thus removing inbreeding as a force promoting homozygosity.

The degree to which populations diverge genetically is primarily determined by the amount of gene flow between them. Even infrequent exchange of genes between populations will prevent genetic divergence as long as the exchange is not solely between close, neighboring populations having very similar gene frequencies (Crow and Kimura, 1970). Since ticks are relatively inactive when they are off the host, the vagility of these parasites, and therefore, the rate of gene flow, depends on host mobility. The absence of genetic divergence between geographical disjunct $A m b$. americanum populations can be explained by its lack of host specificity (ref. Mayr, 1963) and by the mobility of its large hosts, including cattle, deer, and certain rodents and carnivores (Bishopp and Trembley, 1945), all of which can disperse ticks rather broadly. Moreover, the long distance transport of livestock and pets within the range of this tick and the large population sizes encountered throughout its distribution act to reduce interpopulation differentiation.

In summary, Amb. americanum is a variant rich species which shows little interpopulation divergence. That these observations do not agree with expectations can be attributed, in part, to the inappropriate application of the model of Price (1977) to generate predictions about ticks. Comparisons of data from $A m b$. americanum to observations on other ticks suggest that the levels of genetic variation within and between populations of hard ticks are best explained in terms of host mobility, population sizes of both hosts and parasites, and the degree of host specificity exhibited by the tick. Phenotypic homeostasis may also be important, but its effects are more difficult to deduce from available data.

Acknowledgements We would like gratefully to acknowledge the assistance of all those coleagues who supplied us with ticks: Dr D. R. Barnard, Lone Star Tick Research Laboratory, 
U.S.D.A., A.R.S., Poteau, OK.; Dr R. H. Zimmerman, Land Between The Lakes, Tennesse Valley Authority, Golden Pond, KY.; Dr R. H. Roberts, Insects Affecting Man and Animals Research Laboratory, U.S.D.A., Gainesville, FL.; Dr T. R. Adkins, Jr, Department of Entomology, Fisheries and Wildlife, Clemson University, Clemson, S.C.; Dr T. L. Schulze and M. F. Lakat, New Jersey State Department of Health, Trenton, N.J.; and Drs E. C. Turner and P. J. Semtner, Southern Piedmont Research and Continuing Education Center, Virginia Polytechnic Institute and State University, Blackstone, VA. We would also like to thank the Texas Parks and Wildlife Department for assistance in collecting on the state parks in Texas, and Dr James Wangberg for facilitating our collecting at the Texas Tech University Center at Junction, TX. Claudio Castillo gave indispensable technical assistance.

\section{REFERENCES}

AYALA, F, J., TRACEY, M. L., HEDGECOCK, D. AND RICHMOND, R. C., 1975. Genetic differentiation during the speciation process in Drosophila. Evolution, 28, 576-592.

BISHOPP, F. C. AND TREMBLEY, H. L., 1945. Distribution and hosts of certain North American ticks. J. Parasitol. 31, 1-54.

BULL, C. M., ANDREWS, R. H. AND ADAMS, M., 1984. Patterns of genetic variation in a group of parasites, the Australian reptile ticks. Heredity 53, 509-525.

CLAYTON, J. W. AND TRETIAK, D. N., 1972. Amine-citrate buffers for $p \mathrm{H}$ control in starch gel electrophoresis. J. Fish. Res. Bd. Canada 29, 1169-1172.

CROW, J. F. AND KImura, M., 1970. An Introduction to Population Genetics Theory. Harper \& Row, Publishers, New York, $591 \mathrm{pp}$.

HEALY, J. A., 1979a. Phosphoglucomutase polymorphism in the tick Ixodes ricinus. Parasitology 78, 7-18.

HEALY, J. A., 1979b. Analysis of $\alpha$-glycerophosphate dehydrogenase variability in the tick Ixodes ricinus (Acari:Ixodidae). Genetica 50, 19-30.

HILBURN, L. R., 1980. Population genetics of Chironomus stigmaterus Say (Diptera: Chironomidae): H. Protein variability in populations of the southwestern United States. Evolution 34, 696-704.

HILBURN, L. R. AND RAI, K. S., 1981. Electrophoretic similarities and mating compatibility among four species of the Aedes (Stegomyia) scutellaris complex (Diptera: Culcidae). J. Med. Entomol. 18, 401-408.

Hillis, D. M., 1984. Misuse and modification of Nei's genetic distance. Syst. Zool. 33, 238-240.

HOOGSTRAAL, H. AND AESCHLiMANN, A., 1982. Tick-host specificity. Bull. Soc. Entomol. Suisse 55, 5-32.

HUNT, L. M. AND HILBURN, L. R., 1985. Biochemical differentiation between species of ticks (Acari: Ixodidae). Ann. Trop. Med. Parasitol., 79, 525-532.
LEVINS, R., 1962. Theory of fitness in a heterogeneous environment. I. The fitness set and adaptive function. Amer. Natur. 96, 361-373.

LEVINS, R., 1963. Theory of fitness in a heterogeneous environment. II. Developmental flexibility and niche selection. Amer. Natur. 97, 75-90.

LEVINS, R., 1968. Evolution in Changing Environments. Princeton University Press, Princeton, N.J., 120 pp.

MACARThuR, R. AND LeVINS, R., 1964. Competition, habitat selection, and character displacement in a patchly environment. Proc. Natl, Acad, Sci. U.S.A. 51, 1207-1210.

MAYR, E., 1963. Animal Species and Evolution. Belknap Press, Cambridge.

MUELleR, L. D. AND AYALA, F. J., 1982. Estimation and interpretation of genetic distance in empirical studies. Genet. Res. Camb. 40, 127-137.

NEI, M., 1972. Genetic distance between populations. Am. Nat. 106, 282-292.

NEI, M., 1978. Estimation of average heterozygosity and genetic distance from a small number of individuals. Genetics 89 , 583-590.

NEVO, E. 1978. Genetic variation in natural populations: patterns and theory. Theor. Popul. Biol. 13, 121-177.

Oliver, J. H., JR. 1977. Cytogenetics of mites and ticks. Ann. Rev. Entomol. 22, 407-429.

PRICE, P. W., 1977. General concepts on the evolutionary biology of parasites. Evolution 31, 405-420.

PRICE, P. W., 1980. Evolutionary Biology of Parasites. Princeton University Press, Princeton, N.J., 237 pp.

SATTLER, P. W. AND HilbURN, L. R., 1985. A program for calculating genetic distance, and its use in determining significant differences in genetic similarity between two groups of populations. $J$. Heredity 76,400 .

SATTLER, P. W., HILBURN, L. R., DAVEY, R. B., GEORGE, J. E. AND ROJAS AVALOS, J. B. Genetic similarity and variability between natural populations and laboratory colonies of North American Boophilus (Acari: Ixodidae). (In press).

SELANDER, R. K., SMITH, M. H., YANG, S. Y., JOHNSON, W. E. AND GENTRY, J. B., 1971. Biochemical polymorphism and systematics in the genus Peromyscus. 1. Variation in the old-field mouse (Peromyscus polionotus). In Stud. Genet. VI. Univ. Texas Publ., 7103, 49-90.

SNEATH, P. H. A. AND SOKAL, R. R., 1973. Numerical Taxonomy, W. H. Freeman and Co., San Francisco.

SNEDECOR, G. W. AND COCHRAN, W. G., 1967. Statistical Methods, 6th ed. Iowa State University Press, Ames, Iowa.

SOKAL, R. R. AND ROHLF, F. J., 1969. Biometry. W. H. Freeman and Co., San Francisco.

WALLIS, G. P. AND MILLER, B. R., 1983. Electrophoretic analysis of the ticks Ornithodoros (Pavlovskyella) erraticus and $O$. (P.) sonrai (Acari: Argasidae). J. Med. Entomol. 20, 570571.

WEIR, B. S. AND COCKERHAM, C. C., 1984. Estimating F-statistics for the analysis of population structure. Evolution 38 , 1358-1370.

WHITE, M. J. D., 1978. Modes of Speciation. W. H. Freeman and Co., San Francisco.

WRIGHT, S., 1951. The genetical structure of populations. Ann. Eugen. 15, 323-354. 